\title{
5. Sınıf Türkçe Ders Kitabının Toplumsal Cinsiyet Açısından İncelenmesi
}

\author{
Sinem SATILMIŞ*
}

5. Sınıf Türkçe Ders Kitabının Toplumsal Cinsiyet Açısın-
dan İncelenmesi

Özet

Bu araştırma 5. sınıf Türkçe ders kitabının toplumsal cinsiyet açısından ele alınmasını amaçlamaktadır. Araştırma, betimsel araştırma yöntemlerinden doküman incelemesi metoduyla yapılmıştır. Araştırmanın örneklemini 5. sınıf Türkçe ders kitabı metinleri oluşturmaktadır. 5. sınıf Türkçe ders kitabının toplumsal cinsiyet açısından ele alınmasını amaçlayan bu araştırmada toplanan verilerin analizinde betimsel istatistik (frekans(f), yüzde(\%)) analizleri kullanılmıştır. Araştırmanın sonunda Türkçe ders kitabı toplumsal cinsiyet açısından incelenerek erkek cinsiyetinin kız cinsiyetine oranla daha ağırlıkta olduğu sonucuna ulaşılmıştır.

Anahtar Kelimeler: Toplumsal Cinsiyet, Ders Kitabı, Kadın, Erkek

\section{Giriş}

Bireyin eğitim öğretim hayatına atıldığında ilk karşılaştığı eğitim materyallerinden biri olan ders kitapları, bireyin gelişimi açısından bir kaynak olarak kullanılmaktadır. Ders kitaplarının gerek görsel gerek içerik gerekse bireye model olması gibi birçok yönü bireyin gelişiminde büyük etkilere sahiptir. Çünkü birey bir ders kitabından dilini doğru bir biçimde kullanmayı, öğrendiği dilin inceliklerini fark etmeyi, kitaptaki metinler aracılığıyla yaşamı arasında bağlantı kurarak deneyimler elde etmeyi ve dünyaya farklı bakış açılarıyla bakmayı öğrenmektedir (Ayhan, 2010). Bu nedenle ders kitapları oluşturulurken dikkat edilmesi gereken birçok husus bulunmaktadır. Devletin denetiminden geçerek bireylerin eline ulaşan ders kitapları, bir milletin benimsemiş olduğu ideolojiyi, maddi ve manevi

* Sinem SATILMIŞ, Yüksek Lisans Öğrencisi.,Trabzon Üniversitesi Lisansüstü Eğitim Enstitüsü, sinemstlm.8@gmail.com, ORCID ID orcid.org / 0000-0001-8054-2069

Makale Kabul Tarihi 29/03/2019
Investigation Of The 5th Class Turkish Text Books For Social Gender

Abstract

This research aims to address the 5th grade Turkish textbook in terms of gender. The research was done by descriptive research method. The sample of the study consists of the 5th grade urkish textbook texts. Descriptive statistics (frequency (f) percentage (\%)) analyzes were used in the analysis of the data Turkish the grade the Turkish textbook was examined in terms of gender and it was concluded that the male sex was more dominant than the female gender.

Key Words: Social Gender, Text Book, Woman, Man 
kültürü yansıtması bakımından önem teşkil etmektedir. Bununla birlikte ders kitapları bir ülkeye yeni bir kimlik kazandırmayı ve kazandırılan bu kimliğe yeni bir vatandaş yetiştirmeyi tüm açıklığıyla göz önünde bulundurmaktadır(Gümüşoğlu, 2008).

Biçim bakımından ders kitaplarının özellikleri incelendiğinde ise metinde kullanılan cümlelerin bireylere yönelik üslupla, açık ve anlaşılır bir şekilde yazılması söz konusudur (Gümüşoğlu, 2008). Bu özelliklere sahip ders kitapları bireylere yaşamdan örnekler sunarak, bireyin bilişsel, duyuşsal ve psikomotor gelişimini güçlendiren, gereksinimlerini karşılayan ve bireylerin dikkatini çekecek nitelikte olmalıdır. Aynı zamanda Milli Eğitim BakanIığı Ders Kitapları ve Eğitim Araçları Yönetmeliğine uygun, onaylanmış ve Tebliğler Dergisinde yayımlanmış ders kitaplarının başlıca özellikleri aşağıdaki şekilde sıralanmıştır:

-Metinler, Türk Milli Eğitiminin genel amaçlarına ve temel ilkelerine uygun olmalıdır.

-Metinlerde milli, kültürel ve ahlaki değerlere, milletimizin bölünmez bütünlüğüne aykırı unsurlar yer almamalıdır.

-Metinlerde öğrencilerin sosyal, zihinsel, psikolojik gelişimini olumsuz yönde etkileyebilecek cinsellik, karamsarlık, şiddet vb. ögeler yer almamalıdır.

-Metinler, öğrencilerin dil zevkini ve bilincini geliştirecek, hayal dünyalarını zenginleştirecek nitelikte olmalıdır.

-Metinler, öğrencinin gelişimine katkıda bulunacak ve onlara estetik bir duyarlılık kazandıracak nitelikte olmalıdır.

-Ders kitaplarındaki metinler, içeriğe uygun çeşitli görsel materyaller (fotoğraf, resim, afiş, grafik, karikatür, çizgi film kahramanları vb.)in yanı sıra atasözü, özdeyiş, duvar yazısı ve sloganlarla desteklenmelidir (Ülper, 2010: 117-119). Öte yandan ders kitaplarının toplumsal cinsiyet rolleri açısından incelenmesi de çok önemlidir.

Toplumsal cinsiyete duyarlı çalışmalar denildiğinde de kastedilen 'sadece kadınları da dâhil etmek değil' çalışmalarda farklı cinsel yönelimlerin ve ihtiyaçlarının farkında olunması ve bunlara yönelik ayrımcı tutumların dikkate alınmasıdır (Özaydınlık, 2014: 94).Toplumsal cinsiyet birçok unsuru içinde barındıran kapsamlı bir kavramdır. Toplumsal cinsiyet kavramı, kadınlara ve erkeklere yüklenen toplumsal görevlerin veya rollerin olduğunu belirtir. Bu konu üzerine yapılan çalışmalarda amaç sadece kadınları topluma dâhil etmeyi değil, cinsiyet açısından farklı yönelimleri keşfetmeyi, kadın ve erkek arasındaki ayrımcılığı fark etmeyi hedeflemektedir(Kırbaşoğlu ve Eyüp, 2011).

Cinsiyet ve toplumsal cinsiyet kavramlarının anlam bakımından birbirinden ayrılmasının en temel nedeni; cinsiyet fiziksel ve biyolojik özelliklerle, toplumsal cinsiyetin ise etkileşimler ve kültürel ögelerle çizilen çerçeveleridir. Cinsiyet ile ilgili bilgiler evrensel olarak farklılık göstermezken toplumsal cinsiyetin tanımlanması bazı değişkenlerin gözetilmesiy- 
le sağlanmaktadır. Farklı yaşantıların, farklı kültürlerin ve inançların, farklı zaman dilimlerinin etkisi toplumsal cinsiyete dinamik bir nitelik kazandırmaktadır(Yeşil, 2014: 14).

Yapılan araştırmalara göre, ders kitaplarının toplumsal cinsiyet açısından dağııımı şu yönlerden çeşitlilik göstermektedir:

-Toplumsal hayatta erkeği aktif, kadını pasif olarak gösteren örnekler gerek metinlerde gerekse görsel materyallerde öne çıkarılmaktadır(Kılıç ve Eyüp, 2011).

-Kadınlar daha önceki ders kitaplarında daha çok öğretmenlik, terzilik gibi mesleklere uygun görülerek diğer meslek alanlarından dışlanmış durumdadır. Aynı zamanda ders kitaplarında kadının uysal ve uyumlu, temiz ve tertipli, iyi kalpli ve cömert olması konusunda örnekler üzerinde durulduğu göze çarpmaktadır. Erkeklerin ise kadınların aksine daha güçlü kişilik özellikleri ve fiziksel özelliklere sahip oldukları gözlemlenmiştir. Erkek daha çok alışveriş yapmak, evin tamir işleriyle ilgilenmek, araba kullanmak ve evin geçimini sağlamaktadır.

Toplumsal cinsiyet açısından ele alınan özelliklere göre toplumda genel olarak erkeklerin daha güçlü kişilik özelliklerine sahip olduklarını fakat kadınların üzerine yüklenen sorumlulukların erkeklere oranla oldukça geniş bir yelpazeyi içermekte olduğu görülmektedir(Kılıç ve Eyüp, 2011).

\section{Amaç}

2017 Türkçe Dersi Öğretim Programı'nın uygulamaya yeni konulmasından kaynaklanan Türkiye Cumhuriyeti Milli Eğitim Bakanlığı (MEB) Talim Terbiye Kurulunun izniyle okutulan 5. sınıf Türkçe ders kitabının görsellerinin ve içeriğinin toplumsal cinsiyet açısından incelenmesine yer verilmemesi nedeniyle bu çalışmanın yapılması amaçlanmıştır. Araştırma sonunda "Milli Eğitim Bakanlığı Talim Terbiye Kurulu izniyle okutulan ders kitapları cinsiyetçi tavır takınmış mıdır?" sorusuna yanıt bulunacak ve bu bulunan sonuçların ne yönde olabileceği, neler yapılması gerektiği tartışılacaktır.

\section{Önem}

2015-2016 eğitim-öğretim yılı Türkiye İstatistik Kurumu verilerine göre resmi okullarda eğitim gören 14 milyon 540 bin 339 öğrenciden 7 milyon 100 bin 641'i $(\% 48,8)$ kız, 7 milyon 439 bin 698'i $(\% 52,2)$ erkek öğrenciden oluşan sistem içerisinde kız ve erkek öğrencilere aynı metin üzerinden öğretim sunulmaktadır. Bu nedenle metinlerin toplumsal cinsiyet kavramı açısından incelenmesine gerek görülmüştür. Öte yandan önceki yıllarda 5. sınıf Türkçe ders kitabının 2017 Öğretim Programı'na yönelik toplumsal cinsiyet açısından incelenmesine yer verilmemesinden dolayı bu çalışma ayrı bir önem arz etmektedir. 
Sinem SATILMIŞ

\section{Yöntem}

Bu bölümde araştırmanın modeli, evren ve örneklemi, verilerin toplanması ve verilerin analizi ile ilgili bilgiler açıklanmıştır.

\subsection{Araştırmanın Modeli}

Bu çalışma betimsel bir araştırma olup doküman incelemesi yöntemi kullanılmıştır. Doküman incelemesi; araştırılması hedeflenen olgu veya olgular hakkında yazılı materyallerin analizini kapsar. Nitel araştırmada doküman incelemesi tek başına bir veri toplama yöntemi olabileceği gibi diğer veri toplama yöntemleri ile birlikte de kullanılabilir(Yıldırım ve Şimşek, 2008: 187).

\section{2 Örneklem}

Araştırmanın örneklemini ortaokul düzeyinde seçilen MEB Yayınlarına ait 5. sınıf Türkçe ders kitabındaki 8 temaya ait 24 metin, 184 etkinlik ve 224 görsel oluşturmaktadır.

\subsection{Verilerin Toplanması}

Bu çalışmanın verileri, 2017-2018 eğitim- öğretim yılında kullanılan MEB Yayınları 5. sınıf Türkçe ders kitabıdır. Çalışmanın sonunda elde edilen veriler sonuç ve öneriler bölümünde verilmiştir.

\subsection{Verilerin Analizi}

2017-2018 eğitim- öğretim yılında kullanılan MEB Yayınları 5. sınıf Türkçe ders kitabında bulunan toplumsal cinsiyet rollerine ait öğeler doküman incelemesiyle değerlendirilmiştir. Doküman incelenmesinin beş aşaması doğrultusunda çalışmaya yön verilmiştir. Öncelikle incelenecek dokümana karar verilerek MEB Yayınları 5. sınıf Türkçe ders kitabına ulaşılmıştır ve kitabın özgünlüğü kontrol edilmiştir. Sonraki aşamada kitap anlaşılmaya ve çözümlenmeye çalışılmıştır. Çalışma için öncelikle konuyla ilgili veriler kodlanmıştır. Bu kodlama kadın ve erkeğe yüklenen roller doğrultusunda yapılmıştır. Kodlama işleminden sonra elde edilen verilerden hareketle MEB Yayınlarına ait Türkçe ders kitabında bulunan 8 temanın metinleri, görselleri ve etkinlikleri toplumsal cinsiyet kavramı içinde yer alan;

- Cinsiyet

- Yaş aralığı

- Meslek dağılımı

- İsimler

- Kız ve erkek cinsiyetine yüklenen özellikler

- Yazarlar 
açısından incelenmiş, elde edilen veriler de bulgular bölümünde tablo hâlinde verilmiştir.

$\mathrm{Bu}$ araştırmada toplanan verilerin analizinde betimsel istatistik (frekans(f), yüzde(\%)) analizleri kullanılmıştır. Verilerin analizi araştırmacı tarafından yapıldıktan sonra alanında uzman iki akademisyenden daha 5. sınıf Türkçe ders kitabının incelenmesi istenmiştir ve verilerin tutarlılığı kontrol edilmiştir. Farklılık gösteren noktalarda ortak karara varılarak verilerin analizi tamamlanmıştır.

\section{Bulgular}

Tablo 1. 5. sınıf Türkçe ders kitabındaki 8 temanın metinlerinin, görsellerinin ve etkinliklerinin cinsiyet (kız/erkek) açısından incelenmesi:

\begin{tabular}{lcccc}
\hline \multirow{2}{*}{ Tema } & Metinler & Görseller & Etkinlikler & Toplam \\
\hline ÇOCUK & Kız: 4 & Kız: 5 & Kız: 3 & 12 \\
\cline { 2 - 5 } DÜNYASI & Erkek: 5 & Erkek: 11 & Erkek: 10 & 26 \\
\hline MiLLi MÜCADELE & Kız: 5 & Kız: 24 & Kız: 3 & 32 \\
\cline { 2 - 5 } VE ATATÜRK & Erkek: 15 & Erkek: 40 & Erkek: 4 & 59 \\
\hline ERDEMLER & Kız: - & Kız: 1 & Kız: - & 1 \\
\cline { 2 - 5 } & Erkek: 2 & Erkek: 13 & Erkek: 14 & 29 \\
\hline BILIM & Kız: - & Kız: 6 & Kız: 9 & 15 \\
VE TEKNOLOJi & Erkek: 1 & Erkek: 14 & Erkek: 18 & 33 \\
\hline MiLLI KÜLTÜR & Kız: - & Kız: 1 & Kız: - & 1 \\
\cline { 2 - 5 } & Erkek: 4 & Erkek: 17 & Erkek: 6 & 27 \\
\hline OKUMA KÜLTÜRÜ & Kız: 2 & Kız: 7 & Kız: 3 & 12 \\
\cline { 2 - 5 } & Erkek: 2 & Erkek: 13 & Erkek: 3 & 18 \\
\hline SAĞLIK & Kız: - & Kız: 21 & Kız: 1 & 22 \\
VE SPOR & Erkek: 6 & Erkek: 70 & Erkek: 1 & 77 \\
\hline DOĞA & Kız: 1 & Kız: 3 & KIZ: 1 & 5 \\
VE EVREN & Erkek: 1 & Erkek: 13 & ERKEK: 5 & 19 \\
\hline
\end{tabular}

5. sınıf Türkçe ders kitabındaki 8 temanın metinleri, görselleri ve etkinlikleri cinsiyet açısından incelenmiştir. Bu incelemenin sonunda metinler, görseller ve etkinliklerde toplam 405 kişiye yer verilmiştir. Bu kişilerin 100'ünün cinsiyeti kız, 288'inin cinsiyeti erkek, 17 'sinin cinsiyeti ise belirtilmemiştir. 5. sınıf Türkçe ders kitabındaki 8 temanın metinleri incelendiğinde 12 kız 36 erkek, görselleri incelendiğinde 68 kız 191 erkek, etkinlikleri incelendiğinde ise 20 kız 61 erkek cinsiyete yer verilmiştir. 


\section{Sinem SATILMIŞ}

Tablo 2. 5. sınıf Türkçe ders kitabındaki 8 temanın metinler, görseller ve etkinliklerdeki yaş aralığı açısından incelenmesi:

\begin{tabular}{|c|c|c|c|c|c|c|c|c|c|c|c|c|}
\hline \multirow{2}{*}{ TEMA } & \multicolumn{3}{|c|}{ METINLER } & \multicolumn{3}{|c|}{ GÖRSELLER } & \multicolumn{3}{|c|}{ ETKINLIKLER } & \multicolumn{3}{|c|}{ TOPLAM } \\
\hline & $\begin{array}{c}\text { Yaş } \\
\text { Aralığı }\end{array}$ & $\mathrm{KIz}$ & Erkek & $\begin{array}{c}\text { Yaş } \\
\text { Aralığı }\end{array}$ & KIZ & Erkek & Yaş Aralığı & $\mathrm{K} ı \mathrm{z}$ & Erkek & Yaş Aralığı & KIz & Erkek \\
\hline \multirow{4}{*}{$\begin{array}{l}\text { ÇOCUK } \\
\text { DÜNYASI }\end{array}$} & Çocuk & 1 & 3 & Çocuk & 2 & 6 & Çocuk & 1 & 2 & Çocuk & 4 & 11 \\
\hline & Genç & 1 & - & Genç & 1 & - & Genç & 1 & - & Genç & 3 & - \\
\hline & Yetişkin & 2 & - & Yetişkin & 2 & 3 & Yetişkin & 1 & 6 & Yetişkin & 5 & 9 \\
\hline & Yaşlı & - & 2 & Yaşı & - & 2 & Yaşlı & - & 2 & Yaşlı & - & 6 \\
\hline \multirow{6}{*}{$\begin{array}{l}\text { MiLLi MÜ- } \\
\text { CADELE VE } \\
\text { ATATÜRK }\end{array}$} & Çocuk & 1 & 1 & Çocuk & 8 & 15 & Çocuk & 3 & 2 & Çocuk & 1 & 18 \\
\hline & & & & & & & & & & & 2 & \\
\hline & Genç & 1 & - & Genç & 5 & 12 & Genç & - & - & Genç & 6 & 12 \\
\hline & Yetişkin & 2 & 4 & Yetişkin & 9 & 6 & Yetişkin & - & 2 & Yetişkin & 1 & 12 \\
\hline & & & & & & & & & & & 1 & \\
\hline & Yaşlı & 1 & 10 & Yaşı & 2 & 7 & Yaşlı & - & - & Yaşlı & 3 & 17 \\
\hline \multirow{4}{*}{ ERDEMLER } & Çocuk & - & - & Çocuk & 1 & 3 & Çocuk & - & 1 & Çocuk & 1 & 4 \\
\hline & Genç & - & - & Genç & - & - & Genç & - & - & Genç & - & - \\
\hline & Yetişkin & - & 2 & Yetişkin & - & 8 & Yetişkin & - & 10 & Yetişkin & - & 20 \\
\hline & Yaşlı & - & - & Yaşlı & - & 2 & Yaşlı & - & 3 & Yaşlı & - & 5 \\
\hline \multirow{4}{*}{$\begin{array}{l}\text { BILIMM VE } \\
\text { TEKNOLOJi }\end{array}$} & Çocuk & - & - & Çocuk & - & - & Çocuk & 3 & 5 & Çocuk & 3 & 5 \\
\hline & Genç & - & - & Genç & 5 & 1 & Genç & 3 & 5 & Genç & 8 & 6 \\
\hline & Yetişkin & - & _ & Yetişkin & 1 & 12 & Yetişkin & 1 & 3 & Yetişkin & 2 & 15 \\
\hline & Yaşlı & - & 1 & Yaşlı & - & 1 & Yaşlı & 2 & 5 & Yaşlı & 2 & 7 \\
\hline \multirow{4}{*}{$\begin{array}{l}\text { MiLLi } \quad \text { KÜL- } \\
\text { TÜR }\end{array}$} & Çocuk & - & _ & Çocuk & 1 & 2 & Çocuk & - & - & Çocuk & 1 & 2 \\
\hline & Genç & - & - & Genç & - & - & Genç & - & - & Genç & - & - \\
\hline & Yetişkin & - & 2 & Yetişkin & - & 10 & Yetişkin & - & 4 & Yetişkin & - & 16 \\
\hline & Yaşlı & - & 2 & Yaşlı & - & 5 & Yaşlı & - & 2 & Yaşlı & - & 9 \\
\hline \multirow{4}{*}{$\begin{array}{l}\text { OKUMA } \\
\text { KÜLTÜRÜ }\end{array}$} & Çocuk & - & 1 & Çocuk & 6 & 11 & Çocuk & 1 & - & Çocuk & 7 & 12 \\
\hline & Genç & - & - & Genç & - & - & Genç & 1 & 2 & Genç & 1 & 2 \\
\hline & Yetişkin & 2 & 1 & Yetişkin & 1 & 2 & Yetişkin & 1 & 1 & Yetişkin & 4 & 4 \\
\hline & Yaşlı & - & - & Yaşlı & - & - & Yaşlı & - & - & Yaşlı & - & - \\
\hline SAĞLIK & Çocuk & - & - & Çocuk & 12 & 21 & Çocuk & - & - & Çocuk & $\begin{array}{l}1 \\
2\end{array}$ & 21 \\
\hline
\end{tabular}


Eskişehir Osmangazi Üniversitesi Sosyal Bilimler Dergisi

\begin{tabular}{|c|c|c|c|c|c|c|c|c|c|c|c|c|c|}
\hline \multirow[t]{4}{*}{ SPOR } & & Genç & - & - & Genç & - & 7 & Genç & - & - & Genç & - & 7 \\
\hline & & Yetişkin & - & 6 & Yetişkin & 9 & 39 & Yetişkin & 1 & 1 & Yetişkin & 1 & 46 \\
\hline & & & & & & & & & & & & 0 & \\
\hline & & Yaşlı & - & - & Yaşlı & - & 3 & Yaşlı & - & - & Yaşlı & - & 3 \\
\hline \multirow{4}{*}{$\begin{array}{l}\text { DOĞA } \\
\text { EVREN }\end{array}$} & & Çocuk & - & - & Çocuk & - & 6 & Çocuk & - & - & Çocuk & - & 6 \\
\hline & & Genç & - & - & Genç & - & - & Genç & - & - & Genç & - & - \\
\hline & & Yetişkin & 1 & 1 & Yetişkin & 2 & 7 & Yetişkin & 1 & 5 & Yetişkin & 4 & 13 \\
\hline & & Yaşlı & - & - & Yaşlı & 1 & - & Yaşlı & - & - & Yaşlı & 1 & - \\
\hline
\end{tabular}

5. sınıf Türkçe ders kitabındaki temaların metinleri, görselleri ve etkinlikleri cinsiyet açısından (kız/erkek) yaş aralıklarına (çocuk, genç, yetişkin, yaşlı) göre incelenmiştir. Bu incelemenin sonunda 119 çocuk, 45 genç, 171 yetişkin ve 53 yaşlıya yer verilmiştir. 119 çocuğun 40'ı kız, 79'u erkek cinsiyette; 45 gencin 18'si kız, 27'si erkek cinsiyette; 171 yetişkinin 36'sı kız, 135'i erkek cinsiyette; 53 yaşlının ise 6'sının kız 47'sinin erkek cinsiyette olduğu tespit edilmiştir. 5. sınıf Türkçe ders kitabındaki 8 temanın metinleri incelediğinde 2 kız çocuk, 5 erkek çocuk; 2 genç kız; 7 yetişkin kız, 16 yetişkin erkek; 1 yaşlı kız, 15 yaşı erkek cinsiyetine yer verilmiştir. 8 temanın görselleri incelendiğinde 30 kız çocuk, 64 erkek çocuk; 11 genç kız, 20 genç erkek; 24 yetişkin kız, 87 yetişkin erkek; 3 yaşlı kız, 20 yaşlı erkek cinsiyetine yer verilmiştir. 8 temanın etkinlikleri incelendiğinde ise 8 kız çocuk, 10 erkek çocuk; 5 genç kız, 7 genç erkek; 5 yetişkin kız, 32 yetişkin erkek; 2 yaşlı kız, 12 yaşlı erkek cinsiyetine yer verilmiştir. Genel itibariyle yaş aralıkları sıralaması yetişkin (171) , çocuk (119), yaşlı (53), genç (45) şeklindedir.

Tablo 3. 5. sınıf Türkçe ders kitabındaki 8 temanın metinler, görseller ve etkinliklerdeki meslek dağılımı açısından incelenmesi:

\begin{tabular}{|c|c|c|c|c|c|c|}
\hline \multirow[b]{2}{*}{ TEMA } & \multicolumn{2}{|c|}{ METINLER } & \multicolumn{2}{|c|}{ GÖRSELLER } & \multicolumn{2}{|c|}{ ETKINLIKLER } \\
\hline & $K I z$ & Erkek & $K I z$ & Erkek & $K I Z$ & Erkek \\
\hline ÇOCUK DÜNYASI & - & Oyuncakçı & - & Oyuncakçı & - & $\begin{array}{l}\text { Oyuncakçı } \\
\text { Baharatçı }\end{array}$ \\
\hline $\begin{array}{l}\text { MILLI MÜCADELE } \\
\text { VE ATATÜRK }\end{array}$ & $\begin{array}{l}\text { Öğrenci } \\
\text { Ev Hanımı }\end{array}$ & $\begin{array}{l}\text { Sütçü, Asker, } \\
\text { Öğrenci, } \\
\text { Tamirci, } \\
\text { Bakkal, } \\
\text { Kırtasiyeci, } \\
\text { Gazeteci }\end{array}$ & $\begin{array}{l}\text { Çiftçi, Öğren- } \\
\text { ci, Ev Hanımı }\end{array}$ & $\begin{array}{c}\text { Öğrenci, } \\
\text { Tamirci, } \\
\text { Sanatçı, Yazar, } \\
\text { Besteci, Polis, } \\
\text { Asker, Milli } \\
\text { Sporcu } \\
\end{array}$ & - & $\begin{array}{c}\text { Asker, } \\
\text { Ressam, } \\
\text { Öğretmen }\end{array}$ \\
\hline ERDEMLER & - & $\begin{array}{l}\text { Avcı, Çöm- } \\
\text { lekçi }\end{array}$ & - & Avcı, Çömlekçi & & $\begin{array}{l}\text { Avcl, Çöm- } \\
\text { lekçi, } \\
\text { Sözlük } \\
\text { Bilimcisi, } \\
\text { Gölge } \\
\text { Oyuncusu }\end{array}$ \\
\hline
\end{tabular}


Sinem SATILMIŞ

\begin{tabular}{|c|c|c|c|c|c|c|}
\hline $\begin{array}{l}\text { BİLIM } \\
\text { VE TEKNOLOJi }\end{array}$ & Astronot & $\begin{array}{l}\text { Astronot, } \\
\text { Bilim İnsanı }\end{array}$ & $\begin{array}{l}\text { Astronot, } \\
\text { Aşçı }\end{array}$ & $\begin{array}{l}\text { Astronot, } \\
\text { Bilim İnsanı }\end{array}$ & Astronot & $\begin{array}{l}\text { Astronot, } \\
\text { Bilim İnsanı }\end{array}$ \\
\hline MILLI KÜLTÜR & - & $\begin{array}{c}\text { Kaptan, } \\
\text { Asker, Tam- } \\
\text { buri }\end{array}$ & - & $\begin{array}{c}\text { Tamburi, } \\
\text { Kemençeci, } \\
\text { Neyzen, } \\
\text { Filozof, Asker, } \\
\text { Halk Ozanı }\end{array}$ & - & $\begin{array}{l}\text { Asker, } \\
\text { Mimar, } \\
\text { Yüzbaşı }\end{array}$ \\
\hline OKUMA KÜLTÜRÜ & Öğretmen & - & Öğretmen & Öğrenci & - & - \\
\hline SAĞLIK VE SPOR & - & $\begin{array}{c}\text { Binici, Savaş- } \\
\text { çı, Hakem, } \\
\text { Pehlivan, } \\
\text { Davulcu }\end{array}$ & $\begin{array}{c}\text { Öğretmen, } \\
\text { Öğrenci, } \\
\text { Doktor }\end{array}$ & $\begin{array}{l}\text { Vezir, Padişah, } \\
\text { Güreşçi, } \\
\text { Binici, Öğren- } \\
\text { ci, Doktor, } \\
\text { Davulcu, Okçu }\end{array}$ & Doktor & Doktor \\
\hline DOĞA VE EVREN & - & - & - & - & - & $\begin{array}{l}\text { Yazar, } \\
\text { Sanatçı }\end{array}$ \\
\hline
\end{tabular}

5. sınıf Türkçe ders kitabındaki 8 temanın metinleri, görselleri ve etkinlikleri meslek dağılımı açısından incelenmiştir. Bu incelemenin sonunda temalarda "oyuncakçı, öğrenci, ev hanımı, sütçü, asker, tamirci, bakkal, kırtasiyeci, gazeteci, çiftçi, sanatçı, yazar, besteci, sporcu, ressam, öğretmen, çömlekçi, avcı, sözlük bilimci, bilim insanı, gölge oyuncusu, astronot, kaptan, tamburi, kemençeci, neyzen, filozof, halk ozanı, mimar, yüzbaşı, binici, hakem, davulcu, pehlivan, savaşçı, doktor, vezir, padişah, okçu, polis, güreşçi" meslekleri bulunmaktadır. Genel olarak asker, astronot, avcı, doktor, oyuncakçı, öğrenci, öğretmen, sanatçı gibi meslek dallarına yer verilmiştir. Temalarda ön plana çıkan meslek dalları asker, öğrenci, öğretmen ve sanatçı şeklinde sıralanmaktadır.

Tablo 4. 5. sınıf Türkçe ders kitabındaki 8 temanın metinler, görseller ve etkinliklerdeki isimlere göre incelenmesi:

\begin{tabular}{|c|c|c|c|c|c|c|}
\hline \multirow[t]{2}{*}{ TEMA } & \multicolumn{2}{|c|}{ METINLER } & \multicolumn{2}{|c|}{ GÖRSELLER } & \multicolumn{2}{|c|}{ ETKINLIKLER } \\
\hline & $\mathrm{K} \mathrm{IZ}$ & Erkek & $\mathrm{K} \textrm{z}$ & Erkek & $\mathrm{K} ı \mathrm{z}$ & Erkek \\
\hline ÇOCUK DÜNYASI & Alis & Affan Dede & Alis & Affan Dede & Alis & $\begin{array}{c}\text { Affan Dede, } \\
\text { Ligor }\end{array}$ \\
\hline
\end{tabular}


Eskişehir Osmangazi Üniversitesi Sosyal Bilimler Dergisi

\begin{tabular}{|c|c|c|c|c|c|c|}
\hline $\begin{array}{l}\text { MILLI MÜCADELE VE } \\
\text { ATATÜRK }\end{array}$ & Elif & $\begin{array}{c}\text { Hasan Tahsin, } \\
\text { Ömer Halis } \\
\text { Demir, Yunus } \\
\text { Emre, Hacı } \\
\text { Bektaşi, Hacı } \\
\text { Bayram, Koca } \\
\text { Sinan, Mevla- } \\
\text { na, } \\
\text { Pir Sultan } \\
\text { Abdal, Musta- } \\
\text { fa Kemal, Ali, } \\
\text { Mehmet, } \\
\text { Selim }\end{array}$ & Zeynep & $\begin{array}{l}\text { Osman } \\
\text { Zeki, Meh- } \\
\text { met Akif, } \\
\text { Halit Dik- } \\
\text { men, Fazıl } \\
\text { Hüsnü } \\
\text { Dağlarca, } \\
\text { Hacı Bekta- } \\
\text { şi Veli, } \\
\text { Yunus } \\
\text { Emre, } \\
\text { Mevlana, } \\
\text { Pir Sultan } \\
\text { Abdal }\end{array}$ & $\begin{array}{c}\text { Elif, } \\
\text { Ayşe, } \\
\text { Zeynep }\end{array}$ & $\begin{array}{c}\text { Salim, Meh- } \\
\text { met, Mustafa } \\
\text { Kemal, Mert }\end{array}$ \\
\hline ERDEMLER & - & $\begin{array}{l}\text { Karagöz, } \\
\text { Hacivat }\end{array}$ & - & - & - & $\begin{array}{c}\text { Karagöz, } \\
\text { Hacivat, } \\
\text { Tiryaki, Bebe } \\
\text { Ruhi, Laz, } \\
\text { Kayserili, } \\
\text { Çengi, Rume- } \\
\text { lili, Kastamo- } \\
\text { nulu, Kaşgarlı } \\
\text { Mahmut }\end{array}$ \\
\hline $\begin{array}{c}\text { BİLIM } \\
\text { VE TEKNOLOJi }\end{array}$ & - & $\begin{array}{l}\text { Oktay Sina- } \\
\text { noğlu }\end{array}$ & - & $\begin{array}{c}\text { Oktay } \\
\text { Sinanoğlu }\end{array}$ & $\begin{array}{c}\text { Safiye Ali, } \\
\text { Jale İnan, } \\
\text { Halet } \\
\text { Çembel, } \\
\text { Damla }\end{array}$ & $\begin{array}{l}\text { Sinan, Oktay } \\
\text { Sinanoğlu, } \\
\text { Vecihi Hür- } \\
\text { kuş, Halil } \\
\text { İnancık, Cahit } \\
\text { Arf, Fuat } \\
\text { Sezgin, Aziz } \\
\text { Sancar }\end{array}$ \\
\hline MILLİ KÜLTÜR & - & $\begin{array}{l}\text { Kara Memiş, } \\
\text { Turgut Bey, } \\
\text { Cemil Bey, } \\
\text { Niyazi Sayın }\end{array}$ & - & $\begin{array}{l}\text { Neşet Ertaş, } \\
\text { Kemençeci } \\
\text { Kaşif, } \\
\text { Neyzen, } \\
\text { Emin Dede, } \\
\text { Niyazi } \\
\text { Sayın, } \\
\text { Abdurrahim } \\
\text { Karakoç, } \\
\text { Ömer } \\
\text { Seyfettin, } \\
\text { Turgut Bey, } \\
\text { Cemil Bey, } \\
\text { Farabi }\end{array}$ & - & $\begin{array}{c}\text { Kara Memiş, } \\
\text { Turgut Bey, } \\
\text { Mimar Sinan, } \\
\text { Yüzbaşı } \\
\text { Mehmet, } \\
\text { Ahmet Bey, } \\
\text { Ömer Seyfet- } \\
\text { tin }\end{array}$ \\
\hline OKUMA KÜLTÜRÜ & - & - & - & $\begin{array}{c}\text { Ziya Osman } \\
\text { Saba }\end{array}$ & $\begin{array}{c}\text { Ayşe, } \\
\text { Zeynep }\end{array}$ & $\begin{array}{c}\text { Ali, Mehmet, } \\
\text { Hasan }\end{array}$ \\
\hline
\end{tabular}




\section{Sinem SATILMIŞ}

\begin{tabular}{|c|c|c|c|c|c|c|}
\hline SAĞLIK VE SPOR & - & $\begin{array}{l}\text { Atilla İ., Aliço, } \\
\text { Yusuf, Dülger, } \\
\text { Ahmet, } \\
\text { Osman Mes- } \\
\text { tancıoğlu, } \\
\text { Mehmet, } \\
\text { Bekir }\end{array}$ & - & - & Ayşe & $\begin{array}{c}\text { Mehmet, } \\
\text { Mete Gazoz }\end{array}$ \\
\hline DOĞA VE EVREN & - & $\begin{array}{c}\text { Mehmet } \\
\text { Öner }\end{array}$ & $\begin{array}{c}\text { Gülten } \\
\text { Akın }\end{array}$ & $\begin{array}{c}\text { Mustafa } \\
\text { Kutlu }\end{array}$ & - & $\begin{array}{c}\text { Cingöz Recai, } \\
\text { Barış Manço, } \\
\text { Peyami Safa, } \\
\text { Cevat Şakir } \\
\text { Kabaağaçlı }\end{array}$ \\
\hline
\end{tabular}

5. sınıf Türkçe ders kitabında bulunan temaların metinlerindeki, görsellerindeki ve etkinliklerindeki isimler incelenmiştir. İncelemenin sonunda cinsiyetlere göre çoğunlukta olan kız isimleri Ayşe ve Zeynep iken, erkek isimleri Ali, Mehmet ve Mustafa'dır.

Tablo 5. 5. sınıf Türkçe ders kitabındaki 8 temanın metinleri, görselleri ve etkinliklerindeki kızlara ve erkeklere yüklenen özelliklerin incelenmesi:

\begin{tabular}{|c|c|c|c|c|c|c|}
\hline \multirow{2}{*}{ TEMA } & \multicolumn{2}{|c|}{ METINLER } & \multicolumn{2}{|c|}{ GÖRSELLER } & \multicolumn{2}{|c|}{ ETKINLIKLER } \\
\hline & Kız & Erkek & Kız & Erkek & Kız & Erkek \\
\hline ÇOCUK DÜNYASI & $\begin{array}{l}\text { Meraklı, } \\
\text { şaşkın, çok } \\
\text { düşünen, } \\
\text { kendi kendi- } \\
\text { ne konuşan, } \\
\text { sevinçli, } \\
\text { endişeli, } \\
\text { öğütler } \\
\text { veren, }\end{array}$ & $\begin{array}{l}\text { Çocukluk } \\
\text { özlemi } \\
\text { duyan, } \\
\text { utangaç, } \\
\text { oyuncakları } \\
\text { seven, } \\
\text { dalgın }\end{array}$ & $\begin{array}{c}\text { Şaşkın, } \\
\text { duygusal, } \\
\text { kararsız, } \\
\text { heyecanlı, } \\
\text { kitap } \\
\text { okumayı } \\
\text { seven, } \\
\text { dinleyici, } \\
\text { kızgın }\end{array}$ & $\begin{array}{l}\text { Düşünceli, } \\
\text { şaşkın, } \\
\text { sakin, } \\
\text { dinleyici, } \\
\text { hayal eden, } \\
\text { özlem } \\
\text { duyan, } \\
\text { söylenenleri } \\
\text { yanlış } \\
\text { anlayan, } \\
\text { oyuncakları } \\
\text { seven, } \\
\text { temkinli } \\
\end{array}$ & $\begin{array}{l}\text { İstekli, tatlı } \\
\text { yemeyi } \\
\text { seven, } \\
\text { sıkılan, } \\
\text { haber } \\
\text { vermeden } \\
\text { iş yapan, } \\
\text { kitaplar } \\
\text { hakkında } \\
\text { olumsuz } \\
\text { düşünen, } \\
\text { meraklı }\end{array}$ & $\begin{array}{l}\text { Oyuncaklara } \\
\text { ilgi duyan, } \\
\text { dalgın, } \\
\text { unutkan, } \\
\text { utangaç, } \\
\text { dinene } \\
\text { bağlı, } \\
\text { keyfine } \\
\text { düşkün, } \\
\text { itibarlı }\end{array}$ \\
\hline $\begin{array}{l}\text { MILLI MÜCADELE VE } \\
\text { ATATÜRK }\end{array}$ & $\begin{array}{l}\text { Kahramanlık, } \\
\text { özgüven }\end{array}$ & $\begin{array}{l}\text { Cesur, } \\
\text { kahraman, } \\
\text { şaşkın, } \\
\text { sıkılmış, } \\
\text { sinirli }\end{array}$ & $\begin{array}{l}\text { Şaşkın, } \\
\text { mutlu }\end{array}$ & $\begin{array}{l}\text { Özgüven, } \\
\text { sıkılmış, } \\
\text { üzgün, } \\
\text { mutlu, } \\
\text { şaşkın, } \\
\text { düşünceli, } \\
\text { sinirli }\end{array}$ & $\begin{array}{c}\text { Cesur, } \\
\text { kahraman }\end{array}$ & $\begin{array}{l}\text { Utangaç, } \\
\text { kahraman, } \\
\text { zalim, cesur }\end{array}$ \\
\hline
\end{tabular}


Eskişehir Osmangazi Üniversitesi Sosyal Bilimler Dergisi

\begin{tabular}{|c|c|c|c|c|c|c|}
\hline ERDEMLER & - & $\begin{array}{l}\text { Avlanmayı } \\
\text { seven, saf, } \\
\text { kültürlü, } \\
\text { sabırlı, } \\
\text { işinin ehli, } \\
\text { aceleci }\end{array}$ & - & $\begin{array}{l}\text { Çalışkan, } \\
\text { işinin ehli, iş } \\
\text { öğreten, } \\
\text { avlanmayı } \\
\text { seven }\end{array}$ & - & $\begin{array}{l}\text { Dürüst, } \\
\text { sabırlı, } \\
\text { saygılı, } \\
\text { çalışmayı } \\
\text { seven }\end{array}$ \\
\hline $\begin{array}{l}\text { BİLIM } \\
\text { VE TEKNOLOJi }\end{array}$ & $\begin{array}{l}\text { Bilimle } \\
\text { uğraşan, } \\
\text { çalışmayı } \\
\text { seven, } \\
\text { azimli, } \\
\text { becerikli, } \\
\text { yemek } \\
\text { yapan }\end{array}$ & $\begin{array}{l}\text { Bilimle } \\
\text { uğraşan, } \\
\text { çalışkan, } \\
\text { azimli }\end{array}$ & $\begin{array}{l}\text { Bilimle } \\
\text { uğraşan, } \\
\text { yemek } \\
\text { yapan, } \\
\text { çalışkan }\end{array}$ & $\begin{array}{l}\text { Bilimle } \\
\text { uğraşan, } \\
\text { çalışkan }\end{array}$ & $\begin{array}{l}\text { Çalışkan, } \\
\text { bilimle } \\
\text { uğraşan }\end{array}$ & $\begin{array}{c}\text { Çalışkan, } \\
\text { bilimle } \\
\text { uğraşan }\end{array}$ \\
\hline MILLI KÜLTÜR & - & $\begin{array}{l}\text { Savaşçı, } \\
\text { köle, } \\
\text { enstrüman } \\
\text { çalan }\end{array}$ & - & $\begin{array}{l}\text { Enstrüman } \\
\text { çalan }\end{array}$ & - & - \\
\hline OKUMA KÜLTÜRÜ & $\begin{array}{l}\text { Başörtülü, } \\
\text { anne }\end{array}$ & Güler yüzlü & $\begin{array}{l}\text { Kitap } \\
\text { okuyan, } \\
\text { mutlu }\end{array}$ & $\begin{array}{l}\text { Kitap } \\
\text { okuyan, } \\
\text { mutlu }\end{array}$ & - & - \\
\hline SAĞLIK VE SPOR & - & $\begin{array}{l}\text { Cesur, atik, } \\
\text { çevik, } \\
\text { güçlü, yiğit, } \\
\text { delikanlı }\end{array}$ & $\begin{array}{l}\text { Eğlenceli, } \\
\text { neşeli, } \\
\text { sağlıklı }\end{array}$ & $\begin{array}{c}\text { Neşeli, } \\
\text { sağlıklı, } \\
\text { spor yapan }\end{array}$ & - & - \\
\hline DOĞA VE EVREN & - & $\begin{array}{l}\text { Eli sopalı, } \\
\text { oyun } \\
\text { oynayan }\end{array}$ & Sıkılmış & $\begin{array}{l}\text { Oyun } \\
\text { oynayan, } \\
\text { sıkılmış }\end{array}$ & - & - \\
\hline
\end{tabular}

5. sınıf Türkçe ders kitabında bulunan 8 temanın metinlerinde, görsellerinde ve etkinliklerinde kız ve erkek cinsiyetlerine yüklenen özellikler incelenmiştir. Bu inceleme sonunda kız cinsiyetine şaşkın, meraklı, sevinçli, üzgün, sıkılmış, yemek yapan, duygusal, düşünceli, çalışkan, bilimle uğraşan, kitap okuyan vb. roller; erkek cinsiyetine ise cesur, kahraman, çalışkan, güçlü, sabırlı, savaşçı, enstrüman çalan, çevik, atik, bilimle uğraşan, azimli vb. roller yüklenmiştir.

Tablo 6. 5. sınıf Türkçe ders kitabındaki 8 temanın metinlerinin yazarlarına göre incelenmesi:

\begin{tabular}{ccc}
\hline \hline TEMA & KIZ & ERKEK \\
\hline ÇOCUK DÜNYASI & - & $\begin{array}{c}\text { Erdoğan Tokmakçıŏlu, Cahit Sıtkı } \\
\text { Tarancı, Lewıs Carroll }\end{array}$ \\
\hline MiLLI MÜCALEDE VE ATATÜRK & Elif Akardaş & Fazıl Hüsnü Dağlarca \\
\hline ERDEMLER & - & Beydeba, Suat Batur, İskender Pala \\
\hline
\end{tabular}


Sinem SATILMIŞ

\begin{tabular}{ccc}
\hline \hline BiLIM VE TEKNOLOJi & Aslı Zülal, Emine Çaykara & Alberto Douglas Scotti \\
\hline MILLI KÜLTÜR & - & $\begin{array}{c}\text { Abdurrahim Karakoç, Ömer Seyfettin, } \\
\text { Yüce Gümüş }\end{array}$ \\
\hline OKUMA KÜLTÜRÜ & - & $\begin{array}{c}\text { Ziya Osman Saba, Mehmet Necati } \\
\text { Öngay }\end{array}$ \\
\hline SAĞLIK VE SPOR & - & Mehmet Öner, Atilla İlhan \\
\hline DOĞA VE EVREN & Gülten Akın & Mustafa Kutlu, Samed Behrengi \\
\hline
\end{tabular}

5. sınıf Türkçe ders kitabında bulunan 8 temanın metinlerinin yazarları incelenmiştir. $\mathrm{Bu}$ inceleme sonunda 24 metnin içerisinden 21 metnin yazarı belirtilirken 3 metnin yazarına yer verilmemiştir. İsimleri belirtilen 21 yazarın 4'ü kız cinsiyetindeyken, 17'si erkek cinsiyetindedir.

\section{Sonuç ve Öneriler}

MEB Yayınları 5. sınıf Türkçe ders kitabında bulunan 24 metin incelenerek aşağıdaki sonuçlara ulaşılmış ve sonuçlar tablolar hâlinde sunulmuştur. Sunulan verilerde temaların toplumsal cinsiyet üzerindeki etkisi de dikkate alınmalıdır. Ulaşılan sonuçlardan hareketle önerilere yer verilmiştir.

Metinler, görseller ve etkinlikler cinsiyet açısından ele alınmıştır. Elde edilen verilerden hareketle metinler, görseller ve etkinliklerde erkek cinsiyetinin(288) kı cinsiyetine (100) oranla daha ağırlıkta olduğu saptanmıştır (Cinsiyeti belirtilmemiş 17 kişi vardır.). Çeçen (2016) tarafından yapılan çalışmada da Türkçe ders kitaplarındaki metinlerde toplumsal cinsiyet rollerine nasıl yer verildiğini incelenmiştir. Araştırma sonucunda ise metinlerde erkekle birlikte kadının da sosyal hayatta öne çıkmaya başladığı; bununla birlikte erkeğe hem daha fazla oranda yer verildiği hem de erkeğin daha olumlu bir rolde sunulduğu görülmektedir. Bu durumda değişen ve gelişen toplumsal şartlarının ders kitaplarına yeterince yansımadığı ortaya çıkmaktadır.

Yaş aralığı verilerinden hareketle metinler, görseller ve etkinliklerde erkek cinsiyeti kız cinsiyetine göre daha ağırlıkta olup yetişkin yaş aralığının diğer yaş aralıklarına göre daha ön planda olduğu belirlenmiştir. Genel itibariyle yaş aralıkları sıralaması yetişkin (171) , çocuk (119), yaşlı (53), genç (45) şeklindedir.

Meslek dağılımı açısından incelendiğin de meslek dallarından ağılıklı olarak kız cinsiyetine öğrenci ve öğretmen meslekleri yüklenirken, erkek cinsiyetine ise asker, öğrenci, öğretmen ve sanatçı meslekleri yüklendiği sonucuna ulaşılmıştır. Elde edilen verilerden hareketle kız cinsiyeti eğitim süreci içerisinde yer alırken erkek cinsiyeti eğitim sürecine ek olarak askeri alan ve sanat alanında yer almıştır. Erkek cinsiyeti meslek grupları açısından çeşitlilik gösterirken kız cinsiyeti belirli meslek dallarıyla sınırlandırılmıştır. Kırbaşoğlu ve Eyüb (2011) tarafından yapılan araştırmada da benzer sonuca ulaşıldığı görülmüştür ve 
çağdaş bir toplum olmanın ön koşullarından biri olan kadın ve erkek eşitliğinin ders kitaplarında daha titizlikle işlenmesi gerektiği ortaya çıkmıştır.

İsimlerden hareketle elde edilen verilere göre erkek isimleri çeşitlilik gösterirken kız isimleri sınırlı (8) sayıdadır. Temalarda ön plana çıkan bu isimler Türk toplumunda sıkça kullanıldığından dolayı ders kitaplarında da bu isimlere yer verilmiştir.

Genel olarak kız ve erkek cinsiyetlerine yüklenen özellikler kişisel ve fiziksel olmak üzere çeşitlilik göstermiştir. Kız cinsiyetinde kişisel özellikler ön plana çıkarken erkek cinsiyetinde kişisel özelliklere ek olarak fiziksel özellikler de ön plana çıkmıştır. İnceleme sonunda kız cinsiyetine şaşkın, meraklı, sevinçli, üzgün, sıkılmış, yemek yapan, duygusal, düşünceli, çalışkan, bilimle uğraşan, kitap okuyan vb. roller; erkek cinsiyetine ise cesur, kahraman, çalışkan, güçlü, sabırlı, savaşçı, enstrüman çalan, çevik, atik, bilimle uğraşan, azimli vb. roller yüklenmiştir. Türkçe ders kitaplarında seçilen metinler aracılığıyla öğrencilere geniş bir modeller ve etkinlikler yelpazesi sunulmaya çalışılmalıdır ve kalıplaşmış toplumsal cinsiyet rolleri metinler aracılığıyla daha da yerleşik hale getirilmemelidir.

Metinlerde erkek cinsiyetinde(17) olan yazarların kız cinsiyetindeki(4) yazarlara göre daha ön planda olduğu tespit edilmiştir.

5. sınıf Türkçe ders kitabındaki metinler, görseller ve etkinlikler tablodaki özelliklerden hareketle incelenmiş, araştırmanın sonunda toplumsal cinsiyet açısından erkek cinsiyetinin kız cinsiyetine oranla daha ağırlıkta olduğu sonucuna ulaşılmıştır. Bu sonuçtan hareketle MEB Yayınları 5. sınıf Türkçe ders kitabındaki metinlerde, görsellerde ve etkinliklerde yer verilen kız ve erkek cinsiyetlerinin eşit oranda dağılım göstermesi, kız cinsiyeti oranının erkek cinsiyeti oranına yaklaştırılması veya erkek cinsiyet oranının azaltılması gerektiği önerilmektedir. Aynı zamanda günümüzde kız cinsiyeti her alanda aktif hale gelmiştir. Bu durumun kitaplara da yansıtılması gerektiği düşünülmektedir.

\section{Kaynaklar}

Ayhan, Y. (2010). Illköğretim 5. sınıf türkçe ders kitabı resimlerinin biçim ve içerik açısından 11 yaş grubuna uygunluğu ve aynı yaş grubu öğrencilerinin yaptığı resimlerle karşılaştırılması. Yayımlanmamış Yüksek Lisans Tezi, Gazi Üniversitesi Eğitim Bilimleri Enstitüsü, Ankara.

Çeçen, A. (2016). Türkçe ders kitaplarında toplumsal cinsiyet rolleri. İnönü Üniversitesi Eğitim Fakültesi Türkçe Eğitimi Bölümü, Malatya.

Çınar, E.(2013). Ortaokul türkçe ders kitaplarında toplumsal cinsiyet. Yayımlanmamış Yüksek Lisans Tezi, Pamukkale Üniversitesi Eğitim Bilimleri Enstitüsü, Denizli.

Gümüşoğlu, F.(2008). Ders kitaplarında toplumsal cinsiyet. Yayımlanmamış Yüksek Lisans Tezi, Mimar Sinan Üniversitesi, İstanbul. 
Kırbaşoğlu, L. Ve Eyüp B. (2011). Ilköğretim Türkçe ders kitaplarında ortaya çıkan toplumsal cinsiyet rolleri üzerine bir inceleme. Ordu Üniversitesi Sosyal Bilimler Araştırmaları Dergisi, 2/3, 129-148.

Özaydınlık, K. (2014). Toplumsal cinsiyet temelinde Türkiye'de kadın ve eğitim. Sosyal Politika Çalışmaları Dergisi, 33, 94.

Ülper, H.(2010). Türkçe ders kitabı çözümlemeleri. Ankara: Pegem Akademi Yayınları.

Yeşil, F. (2014). Ortaokul Türkçe ders kitaplarında cinsiyet ifadeleri ve toplumsal cinsiyet rolleri. Yayımlanmamış Yüksek Lisans Tezi, Marmara Üniversitesi Eğitim Bilimleri Enstitüsü, İstanbul.

Yıldırım, A., \& Şimşek, H. (2008). Sosyal bilimlerde araştırma yöntemleri. Ankara: Seçkin Yayıncilık.

Yorgancı, F. (2008). Illköğretim ders kitaplarında toplumsal cinsiyet rollerinin inşası. Yayımlanmamış Yüksek Lisans Tezi, Afyon Kocatepe Üniversitesi Sosyal Bilim Enstitüsü, Afyonkarahisar. 